\title{
Towards interdisciplinary rural research - theorizing nature-society relations
}

\author{
Karl Bruckmeier \\ Sociologist, School of Global Studies, Gothenburg University, Gothenburg, Sweden
}

\begin{abstract}
Les articles de Karl Bruckmeier et de Hilary Tovey ont tous deux pour origine le XXIII e congrès de l'European Society for Rural Sociology intitule "Reinventing the rural: between the social and the natural" qui s'est tenu en 2009 à Vaasa en Finlande. Les auteurs y adoptent un même objectif : discuter de la capacité de la sociologie rurale à construire une position théorique robuste « entre le social et le naturel » et, par là même, à se positionner par rapport à l'interdisciplinarité. Mais, alors même qu'ils s'appuient sur un état de l'art symétrique montrant l'ampleur de leurs références scientifiques, bien qu'anglophones pour l'essentiel, les auteurs proposent aux lecteurs un dialogue en confrontant leurs points de vue qui s'opposent. K Bruckmeier appelle à une nouvelle approche critique de la ruralité ouverte aux changements des rapports sociétés/natures et à l'interdisciplinarité. H. Tovey répond en lui opposant une analyse partant de la sociologie rurale pour évaluer sa capacité à inventer les approches épistémologiques et méthodologiques répondant aux nouveaux problèmes posés. Dans le droit fil du dossier ouvert dans NSS sur l'interdisciplinarité (NSS, 12, 1 [2004] et suivants), ces deux articles montrent que le débat sur les questions interdisciplinaires touche bien tous les champs disciplinaires.
\end{abstract}

La Rédaction

\section{Keywords:}

rural sociology; interdisciplinarity; interaction of society and nature; social ecology; global change

\section{Mots-clés :} sociologie rurale ; interdisciplinarité ; interactions société-nature ; écologie sociale ; changement global
Abstract - This article deals with the significance of interdisciplinary rural and environmental social research for the theorization of society and society-nature relations. For this purpose fields of knowledge adjacent to rural sociology are reviewed: environmental sociology, human and social ecology, ecological economics, social-ecological systems analysis, research on common pool resources and environmental conflicts. In discussing themes, concepts and reflections about the relations between society and nature, it is shown how theoretical codification and reflection on knowledge as well as knowledge application for natural resource management can develop from interdisciplinary research. Rural sociology can gain from the interdisciplinary knowledge exchange without changing its specialization as sociological subdiscipline.

\begin{abstract}
Résumé - Pour une recherche rurale interdisciplinaire : théorisation des relations naturesociété. Cet article se propose d'évaluer les apports de la recherche rurale et environnementale en sciences sociales à une théorie des relations entre nature et société. Plusieurs champs de recherche proches de la sociologie rurale sont discutés : la sociologie de l'environnement, l'écologie humaine et sociale, l'économie écologique, l'analyse des systèmes socioécologiques, la recherche sur les "common pool resources" et sur les conflits d'utilisation des ressources naturelles. La discussion des thèmes, concepts et réflexions sur les relations entre nature et société résultant de ces différents champs de recherche interdisciplinaire montre qu'ils peuvent contribuer à la codification et à la théorisation réflexive des connaissances ainsi qu'à leur application pratique dans les sphères de la gestion des ressources naturelles. La sociologie rurale peut ainsi s'enrichir d'un nouveau savoir en mettant à l'épreuve la théorie socioécologique des relations entre nature et société sans qu'elle ait à changer son identité en sous-discipline sociologique.
\end{abstract}

\section{Introduction - variants of interdisciplinary rural research}

Several interdisciplinary fields of research about environment and natural resources, thematically close to rural sociology, developed in the past decades. Beyond the sociology of the environment and natural resource use, ecological economics, human, social and political ecology,

Corresponding author: karl.bruckmeier@globalstudies.gu.se common pool resource research, research about global environmental change, analysis of social-ecological systems are discussed here, with the focus on ecological knowledge and theory development. Common themes of these subjects are natural resource use, including land and water use, and environmental problems, pollution and modification of ecosystems through human use. Further areas, e.g. rural studies, rural research in geography, economics and political science are not discussed, 
assuming that the ones mentioned before are more interdisciplinary, influential and oriented to natural resource use. How a theory of nature-society relations develops from research in these areas is of interest here. Theoretical discourses, in rural sociology and in these fields, are less advanced than empirical research. Such "undertheorizing" is a justification for discussing the development of a theory of nature-society interaction and its implications for rural research ${ }^{1}$.

\section{Interdisciplinary perspectives for nature-society interaction}

Interdisciplinarity is discussed in variants of multi-, inter- or transdisciplinarity. In the definition of Klein (1990) it means the synthesis of two or more disciplines, establishing a new level of discourse and integration of knowledge. The discussion about interdisciplinarity and more recently about transdisciplinarity, where non-scientific knowledge is taken up in research (Nowotny et al., 2001), has not resulted in clear differentiations between disciplinary, pluri- or multidisciplinary, interdisciplinary, transdisciplinary and non-disciplinary knowledge. There are no sharp boundaries between scientific knowledge practices; these can rather be seen in a continuum of gradually varying practices of knowledge generation, integration, dissemination and application with many forms between the two extremes of disciplinarity and non-disciplinarity. The concepts remain vague, aims and forms of interdisciplinary research are manifold, need to be described from empirically based, historically specified typologies, as e.g. Jamison (2001) tried for different knowledge regimes. Also the reference term "scientific disciplines" is vague, its main purpose being to define organizational boundaries of knowledge in academic knowledge production and dissemination. Interdisciplinarity was for a long time seen as development outside of and critical towards disciplinary specialization. This changed in recent years with the discussion about hybrid specialization (Dogan, 1996) and interdisciplinary research becoming part of many disciplines and academic agendas. The conclusion that "established academic disciplines remain dynamic centers of knowledge production that are open to external developments even while insisting on internal standards" (Jacobs and Frickel, 2009, p. 60) can be doubted for several reasons. Interdisciplinarity is analyzed by Jacobs and Frickel only as that in academic research, with a vague and undifferentiated notion of interdisciplinarity and limited to universities in the USA. In the following discussion the

1 This paper was originally drafted as contribution to the 2009 European Society for Rural Sociology's conference in Vaasa, Finland, on "Reinventing the rural: between the social and the natural" - specifically to Theme 4, "The sciences of the rural". term interdisciplinarity is used for different practices of knowledge production, exchange and integration that have in common a critical attitude towards specialization of disciplines and analysis of complex social and environmental problems.

\section{Interdisciplinarity in environmental social sciences developing within disciplinary knowledge cultures}

\section{Environmental sociology and sociology of natural resource use}

A large part of human influences and modifications of ecosystems or natural resources happens through agriculture, modifying ecosystems strongly (Millennium Ecosystem Assessment, 2005). The forms and effects of such modifications of nature by man are not systematically investigated in rural sociology although environmental problems have gained attention there. Research about natural resources is the core theme in analyzing the interaction between nature and society across global, national and local scales; it is of relevance for rural sociology with the globalization of food production and trade that can be seen as part of this larger topic.

The sociology of natural resource use has other intellectual sources and traditions than environmental sociology, but the division is not strict (Buttel, 2002). It may be seen as part of environmental sociology developing since the 1970s in Western countries with a variety of themes, approaches and methods. Catton and Dunlap (1980) formulated a still influential variant of environmental sociology that was also part of the renewal of human ecology in the 1970s. This sociology is critical towards the sociological tradition where nature and the physical environment are seen as separate from society. Knowledge about nature and the problems resulting from nature-society interaction seems self-evidently provided from physics, biology and ecology. However, the differentiation between natural and social sciences prevents a theoretically guided reconstruction of societal interaction with nature that was tried in recent decades only by few authors, e.g. Moscovici (1968).

Catton and Dunlap argued for the inclusion in sociological analysis of physical, biological and ecological data. Among their further ideas the distinction between the Human Exemptionalism Paradigm (HEP) and the New Ecological Paradigm (NEP) or between anthropocentric and ecocentric perspectives is discussed until today, showing that academic knowledge is not isolated from normative knowledge and culturally specific views of nature, man and society. But also worldviews or paradigms are not sufficient to account for the interaction between society and nature in dealing only with their symbolic components. 
Societal relations to nature vary historically with the structures of human societies and are not easy to grasp in sociological analyses of modern societies. These relations require critical, theoretically based analysis of the systems of society, economy and nature to identify their destructive (e.g. environmental disruption, alienation), integrative (e.g. traditional and new practices of sustainable resource use), and differentiating (e.g. manifold socio-cultural practices of natural resource use) components. Historical antecedents of a critical analysis of interaction of society and nature can be found in the discourses of critical theory and political economy from Marx's analysis of societal metabolism relating to Liebigs' theory of agriculture up to the renewal of political economy within human ecology and environmental sociology (Schnaiberg and Gould, 1994) and the present discourse of ecological Marxism (Foster, 1999). Diagnoses that human society dominates nature or the other way round that it should be part of nature or following nature's lead, are more part of a problem than of a solution. They are too general and abstract to provide for adequate sociological answers to the present crisis in nature-society interaction. Most environmental movements see society as part of nature or ecosystems, which remains convincing and misleading simultaneously, suffering from a truncated analysis of society-nature interaction, as does the opposite HEP-perspective. Beyond the analysis of symbolic relations a critical analysis of material processes, resource flows and the global economic system or modern world system is required. Historical variations of coupled nature-society systems can be analyzed in terms of human labor, resource use and management, societal metabolism or matter and energy flows between social and ecosystems, and conflicts about the distribution and use of natural resources, to mention some of the core concepts in a theory of nature-society interaction. More recent environmental sociology (Mol, 2008) comes closer to an analysis of socially organized material and energy flows, core processes of nature-society interaction. However, the theory of ecological modernization from which it is developing has, with all the changes since the 1980s, not developed a critical systems analysis of globalized capitalism of its own; it is still influenced by its earlier diagnoses of adaptation of environmental movements to dominant political and economic interests and has no detailed quantitative analysis of the resource flows it is discussing, as meanwhile found in the socio-ecological discourse.

"Societal relations to nature" (Becker and Jahn, 2005 and 2006) codify mans' historically varying interactions with nature in different societies as conflicting, integrative or differentiating, and include material-energetic and symbolic components in culturally varying interpretations of nature and man from philosophy of nature or philosophical anthropology to everyday views of world, nature and man. To integrate physical and ecological knowledge in sociological analysis as Catton and Dunlap demanded requires other conceptual and theoretical frameworks than theirs to show how the material and symbolic components are mediated and why the impression of separation has emerged (see below, social ecology).

The interaction between social factors of ownership, access and distribution of natural resources, with natural factors described e.g. as ecosystem functions and services, cannot be explained by way of empirical research only. In-depth analysis of the historically changing forms of unequal access, exchange and distribution of natural resources that result in resource overuse, poverty and hunger in historical and modern societies requires the integration of empirical and theoretical knowledge. When, why and how the non-intended consequences of agricultural resource use, hunger and deterioration of the natural resource base, have become permanent are questions in the environmental discourse in science and policy. The paradox formulated by Destutt de Tracy that "'in poor nations people are comfortable' whereas in rich nations 'they are generally poor"' (Sahlins, 1972, p. 2) still needs to be discussed further. Hunger and poverty are no longer episodic phenomena caused by inefficient agricultural practices or natural hazards that threaten a local society as a consequence of bad harvests and following famines. Rather they became a "syndrome of modernization" with its forms of unbalanced development of rural and urban, agricultural and industrial production. In European sociology certain historical cases of famines have been studied, in Ireland (Geary, 1997) or Russia (Sorokin, 1975) for example. The "permanent global famine" has been less studied; an integrated theory to replace the shortcut diagnoses of Malthusian and Neo-Malthusian thinking that hunger and overuse of natural resources result from rapid population growth, not from unequal appropriation, distribution and consumption of natural resources, is still lacking.

The relevance of environmental sociology for rural sociology, beyond the "twinning" of specialized research fields and combining data and results from research, can be that of driving the critical analysis of nature-society interaction further than in rural sociology (Walker, 2005). That would require theoretical reflection on the problems touched upon here: unequal access to and distribution of natural resources, unequal exchange, the societal metabolism of matter and energy flows between nature and society. Some of these topics are discussed further in ecological economics.

\section{Ecological economics}

Ecological economics developed in critical relation to more conventional environmental economics. Its roots can be seen in critical institutional economics with 
Polanyi's (1944) analysis of the "disembedding" of modern capitalist market economy, where the risk of social disintegration and environmental disruption was diagnosed, or Kapp's (1950) "Social costs of private enterprise", where environmental problems resulting from private property and market economy have been analyzed as negative external effects. In the second half of 20th century ecological economics emerged with the pioneering work of Georgescu-Roegen's (1971) thermodynamic analysis as knowledge base for resource use economics and Kenneth Bouldings (1993) analysis of the limits of resources with the "spaceship earth"-metaphor. Daly (1992) developed further the older idea of "steady state" economy. Martinez-Alier (1995 and 2004) studied "ecological distribution conflicts" in the globalizing economy and the "environmentalism of the poor". This heterodox economic thinking is unified by an interest in "physical economy" and material- and energy flows. Ecological economics develops in parallel to the socioecological system analysis discussed below, analyzing societal metabolism and phenomena in the present global economy to identify possible transformation paths towards a more sustainable economy and society. The crisis in present society-nature interaction is described in recent debates in ecological economics with two critical concepts relevant for a theoretical reconstruction of naturesociety interaction: ecological distribution conflicts and unequal ecological exchange, the latter also discussed in critical environmental sociology.

The concept of ecological distribution conflicts has been introduced by Martinez-Alier (1995, p. 80), referring to "the social, spatial, and temporal asymmetries or inequalities in the use by people of environmental resources and services, i.e. in the depletion of natural resources (including the loss of biodiversity), and in the burdens of pollution" that evokes conflicts from local to global levels. His typology includes conflicts about extraction, transport, waste and pollution through global resource flows that reflect the older division of the global economy into periphery and centre as formulated in world system theory. To formulate preconditions for a new environmentally and socially balanced economy, Sachs' (2000) analysis of people, markets and the state in mixed economies may be helpful. It supports a critical analysis of power and property relations in the international economy. Without clear theoretical aspirations this has been taken up in the debates about environmental justice. The analysis of conflicts related to unequal exchange becomes finally part of a critical theoretical analysis of the modern world system in its historical development (Wallerstein, 1974; Wolf, 1982; Hornborg et al., 2007).

Ecological unequal exchange implies a critical analysis of global resource flow, the "material throughput of the world-system" or its socio-economic metabolism, "the disproportionate utilization of ecological systems and externalization of negative environmental costs by developed countries", shifting environmental burdens to the least developed countries (LDCs). Large parts of the resources consumed today in Western countries are globally traded and imported. Asymmetric resource flow from extractive economies (LDCs) to productive economies (industrial countries) supports the positional advantage of the latter in appropriating large parts of global resources, especially energy resources (Rice, 2007) ${ }^{2}$. Both concepts of ecological distribution conflicts and unequal exchange help to identify and systematically analyse spatial and social distortions in the global economy: unequal access to or appropriation of resources, unequal consumption of resources, consequences of differences between countries in the North and South in wealth and welfare in terms of gross domestic product or human development.

In ecological economics problems of natural resource use are studied from statistical data about monetary and resource flows between countries and economies. Resource flows can be analysed along the whole chain of extraction, production, distribution and consumption processes. The relevance of ecological economics for rural sociology can be seen in empirical and theoretical analyses of "systemic distortions" of the global economic exchange processes as highlighted in the phenomena of ecological distribution conflicts and unequal ecological exchange. The systemic nature of global resource flows is further analysed in social ecology.

\section{Interdisciplinarity in environmental research across the boundaries of natural and social sciences - human, social and political ecology}

The interdisciplinary subjects of human, social and political ecology are far from being unified and coherent in their use of knowledge from several natural and social sciences. They are less academically oriented and disciplinarily specialized, more problem centred than environmental sociology or ecological economics. Human ecology, reemerging internationally as critical interdisciplinary subject in the 1970s, studies the interrelations between man, society and nature in interdisciplinary perspectives and with a focus on environmental problems. Social ecology became known as a social movement linked with the eco-anarchism of Bookchin (2005), but it

\footnotetext{
2 "By importing natural resources and exporting sink capacity demand and environmental costs inhabitants of core countries can mistakenly perceive their lifestyles as sustainable, as their consumption rates are not highly linked to domestic environmental conditions [...]. Conversely the rich-countryillusion effect implies that LDCs are to blame for failure to sustain their domestic natural capital" (Rice, op. cit., p. 63).
} 
is understood here differently: as a new interdisciplinary science of nature-society relations that unfolded in the past two decades in Germany (Becker et al., 1992; Becker and Jahn, 2005 and 2006) and Austria (Fischer-Kowalski and Haberl, 2007). Political ecology is a multifaceted critical discourse about nature, society and power structures in resource use, with many different approaches (Forsyth, 2003; Robbins, 2004); it is partly linked to anthropological research about environmental problems, partly to the discourse of political economy and critical theory of modern society, partly to environmental history (Hornborg et al., 2007) ${ }^{3}$. Escobar's (1999) constructivist political ecology can be used as an example to illustrate differences in theoretical construction of socio-ecological regimes in social ecology. In the latter the analysis of historical and distinctive features of the global economy or the modern world system is the critical reference, also when local resource use systems are studied. In Escobar's typology of organic, capitalist and techno-nature regimes the analysis of societal systems collapses, in spite of the aspiration to combine the cultural and the biological on constructivist grounds, into analytical or ideal type constructions to show empirical differences and variations of nature regimes. The theoretical construction of "societal relations to nature" in social ecology and concomitant concepts such as modes of production or socio-ecological regimes allow for systematic description of the historical systems of society interacting with nature.

\section{"Societal relations to nature"}

Society's interaction with nature is described for modern societies in naturalistic, idealistic or technocratic diagnoses of an "environmental crisis". Against these Becker et al. (1992, 171f) ${ }^{4}$ develop a more complex description of present environmental problems:

1. "In crisis" are neither nature nor the environment, but the societal forms of material and symbolic interaction between nature and society in late modern capitalism, called "societal relations to nature".

2. Scientific, economic, political means for crisis management are part of the societal dynamics of that crisis in nature/society interaction and can also contribute to deepen the crisis; the "right" knowledge is difficult to find.

3. Societal agency with regard to the regulation of societal relations to nature is to be enlarged; it cannot be limited to symbolic, inner-societal forms of communication about nature in society, needs to encompass

\footnotetext{
${ }^{3}$ In a more detailed discussion of the political ecology discourse variants should be included e.g. from the French regulation school, from Lipietz (2003), interdisciplinary approaches to integrate ecology and political economy (Enzensberger 1973; Bahro, 1978), or recent combinations of political ecology and environmental history (Hornborg et al., op. cit.).

4 See also Becker and Brand (1996, 121ff).
}

all material and non-material components of the interacting society and nature.

4. Also prior and other social problems in modern capitalism become included in the global crisis (global division of labor, social, political and military power, social, ethnic and gender-specific forms of discrimination and social exclusion etc.).

\section{Material and energy flows in analyses of social-ecological systems}

The diagnosis of a global crisis in the interaction between nature and society can be analyzed further with the concepts of societal metabolism, including the flow of materials and energy in social-ecological systems. Social-ecological systems as connected systems of society and nature in historically varying forms can be described through their socio-ecological regimes (SER), a broader concept than that of modes of production. Such regime description (following Fischer-Kowalski, 2007) shows the problems that come up with system transformation. An SER can be described by its "metabolic profile" (system of energy and materials use measured per capita of human population); a certain pattern of use and change of nature/environment: land-use, resource exploitation, pollution, effects for biological evolution (colonization of nature); a resource management system with the help of infrastructures (transport and communication systems) and specific technologies (in agricultural, industrial production); by its specific economic and political/governance institutions (market order, national and international political systems); and/or by its pattern of demographic reproduction, structuring of human life time and labor/employment structure. Between the different components of an SER (its socioeconomic system and its natural environment) positive and/or negative feedbacks are possible.

The relevance of human and social ecology for rural sociology with its theory-bound research can be seen in in-depth quantitative and qualitative analyses of flows of materials and energy and of ecological distribution conflicts linked to the unequal flows. The flows are not bound to rural areas although most of the resources exchanged originate there. Global flow analysis shows globalization of food production as part of an overarching system in historically specific forms of societal metabolism and socio-ecological regimes. However, the different conceptual components of nature-society interaction in the dispersed fields of environmental sociology, ecological economics, human, social and political ecology are not integrated. A first step was the seminal study of Debeir et al. (1986) to develop a critical interdisciplinary concept of energy system through historical analysis. Whether further interdisciplinary fields of research contribute to developing a theoretical analysis of societal relations to nature needs to be discussed further. 
So far no ecological research about ecosystems and their change through human resource use has been touched. This can be done in looking at transdisciplinary fields of research.

\section{Transdisciplinary fields for the study of nature-society interaction}

The environmental research unfolding under transdisciplinary perspectives, e.g. in "sustainability science", converges with common pool resource research and SESanalysis that develop from applied ecological and interdisciplinary research.

\section{Common pool resource research}

Common pool resource research developed from controversial debates about the "tragedy of the commons" (Hardin, 1968), especially in the work of Elinor Ostrom and her co-researchers. Common pool resources are of many different kinds, not limited to natural resources. They are difficult to deal with, at least in economic analysis, where they appear as combining components of public and private goods, with problems in attributing ownership rights to such resources that are analyzed in local case studies, mainly in rural areas and resources in agriculture, forestry and fisheries. The local knowledge of resource users is of interest here. How it connects with scientific knowledge is seen as a main methodological and epistemological problem in the emergent transdisciplinary research.

In contrast to the subject areas discussed above those discussed here are characterized by skepticism about theory and oriented towards empirical research. Their theoretical concepts develop from empirical research (Ostrom, 2009) in a similar way to grounded theory. The local specificity of knowledge and manifold social practices shows the variety of natural resource use in the modern world system. As the classical study by Wolf (1982) has demonstrated paradigmatically, the macroscopic perspective of the theory of the modern world system needs to be complemented by a microscopic analysis to show the local, socio-cultural and ecological variations of resource use practices that maintain the global system.

Ostrom has on several occasions summarized and synthesized the research about common pool resources. Also the limits of such research in dealing with the complexity of resource use systems have been critically discussed (Agrawal, 2003), approaching the analysis of large scale and global systems. Becker and Ostrom (1995) summarized the preconditions of success for local resource management systems that suffice as criteria of sustainability: creation of social capital (trust, networks, cooperation) and cultural capital (maintaining or renewing traditional resource use practices); improvement of rights, power and qualification of resource users; access to markets, capital, investment by local users; improvement of risk management and limiting risks (precaution). The conclusions about sustainable solutions of resource use by Ostrom (2009) and Acheson (2006) are: standardized or panacea solutions to resource use problems are not possible and property rights alone do not create solutions that can be generalized. Neither private nor state nor common property forms seem sufficient to identify paths of sustainable resource management. Their arguments support calls for better contextualizing resource management and for developing strategies of management in which the problems of resource use can be dealt with as multi-scale problems (Young et al., 2006; Ostrom, 2009):

- creating connections and feedback (between social and ecological systems, across temporal and spatial scales, local and global levels);

- creating resilience (to improve capacity to maintain social and ecosystem functions/services after disturbance and catastrophes);

- collective learning (as part of sustainability: identifying traps, learning from conflicts, finding "escape routes", "planning for the unexpected");

- creating robust solutions (socially robust management systems through integration of scientific, managerial and local knowledge, "adaptive governance").

Analyses of this kind, illustrating the interaction between local and global flows, can e.g. help to analyze critically the complexity of bioenergy production in the global economy. To do that, research on common pool resource management needs to be connected to the analysis of social-ecological systems and to the more critical theoretical analysis of the global system in social ecology.

\section{Analysis of social-ecological systems (SES)}

Social-ecological systems (SES) ${ }^{5}$ is emerging from ecological research, as the terminology shows. It adopts social-scientific knowledge gradually, not necessarily in theory-guided forms. SES-analysis develops along the lines of prior common pool research through empirical research on ecosystem management in local social-ecological systems, with vague guiding ideas, e.g. metaphorically formulated as "navigating SES" or

5 "A social-ecological system consists of a bio-geo-physical unit and its associated social actors and institutions. Socialecological systems are complex, adaptive and delimited by spatial or functional boundaries surrounding particular ecosystems and their problem context. [...]. Adaptive capacity and transformability refers to system ability to change. The former where the objective is to maintain existing systems and the latter where existing systems are found undesirable or characterized by emergent systemic failure, implies change." (Glaeser et al., 2007, 193f). 
"adaptive management". The argument from which the concept of coupled social-ecological systems develops is that of a misleading analytical separation of the two system components in a reified separation of two reality spheres; in contrast to that social and ecological systems are seen as connected. Critical as the idea may be in its intentions, it remains unclear and ambiguous, can easily be understood as a reification of the opposite kind: that society needs nothing else but subordinating to nature or ecosystems, other ideas being wrong thinking or a symptom of alienation of man from nature that can be cured only by ecological thinking and knowledge. A historically more informed view takes into account that throughout history societies developed with more or less "violation" and modification of nature, without being able to dissolve their dependence on nature, in the long run increasing, not reducing, their use of natural resources. Societies succeeded for a limited time only to find co-evolutionary paths of social and ecosystem development that stabilize their interaction, in continuous search for energy resources and new metabolic regimes. This can be seen in large empires in history, in the transition from agricultural to industrial systems, and in modern capitalism, where the transition from coal to oil and then to renewable energy regimes in a short time indicates the accelerating crisis of global materials and energy use. For such analyses the approaches of common pool resource research and SES seem too limited in their concepts and spatial dimensions.

Most recent research about social and hybrid networks, social cooperation, power relations, conflict mitigation, environmental distribution conflicts, unequal exchange and the consequences of global resource flows is not yet systematically connected to SES. SES analysis created unfulfilled expectations that empirical research can be connected with the theoretical concepts discussed above for social ecology, leading to more coherent knowledge about nature-society interaction. Its innovative component may be a more systematic integration of social scientific and natural scientific knowledge in interdisciplinary environmental research.

\section{Research about global environmental change}

The complexity of man-made environmental changeespecially climate change and biodiversity reduction has resulted in research about global processes and global ecosystems where the interaction between society and nature has achieved a complexity that seems beyond the knowledge and management capacities provided by science. However, with the discourse of sustainable development these questions resurface as practical ones.

Climate change and biodiversity research, e.g. about social and ecological resilience and disaster management, addresses successively the complex problems of natural resource use created by global environmental and social change. However, the research is dominated by the natural sciences and a more traditional understanding of research as discipline-based, although the transdisciplinary ideas of sustainability science are connected to $i^{6}{ }^{6}$. The paradigm shift in ecology (Bengtsson et al., 2003) is not yet realized in the practice of climate research.

Global change research highlights the limits of managing natural resources and ecosystems by way of varying socio-ecological regimes, supporting a conclusion from prior ecological research, that ecosystems are too complex to be managed. What is required instead has a preliminary name, "adaptive management" (Ludwig, 2001), developing from case-based learning, rejecting hierarchical, linear, standardized management principles. For theoretical codification of research about complex ecosystem processes and human influence on these syntheses such as the Millennium Ecosystem Assessment are available. The empirical knowledge dispersed in many specialized areas of research cannot be integrated in one coherent, universal theory, but requires framing in several, loosely coupled theories at different levels of analysis. A series of critical questions arises with regard to the limits of knowledge and such theoretical synthesis.

- Knowledge about complex systems such as SES or the climate system depends on models of these systems. Modeling the interaction of social and ecological systems has been done with different types of ecosystem services (provisioning, regulating, cultural services; Millennium Ecosystem Assessment, 2005). The conceptual model is not linked to more theoretical analyses of unequal resource flows although these are visible behind locally and regionally varying environmental problems. Whether system modeling or theory guided analysis are competitive or mutually supporting variants of analyzing complex systems remains a controversial question. Modeling can be seen as a step in the theoretical codification of scientific knowledge. The global models for resource use trends and climate change can be supported by the development of new theories of global nature-society interaction in social ecology (see above) and in ecology (e.g. the emerging theory of the anthropocene by Steffen et al., 2007) to understand the interaction of global social and environmental change factors.

- Major problems of SES are not yet addressed or solved in research and resource management: the main negative development trends continue (biodiversity

\footnotetext{
6 The research on ecological and social-ecological resilience that has developed fast during the past decade (Folke, 2006) is, in spite of manifold variants of the resilience concept, not yet advanced to include systematically social-scientific research and critical theoretical research as discussed here. It remains a social system analysis in ecological or naturalistic forms.
} 
loss, species extinction; overuse of resources; nutrient loading of ecosystems; loss of wetlands and forests as buffers); demographic processes and livelihood changes in the transition to sustainable development are difficult to manage; modernization that increases resource demand/use still goes on and annihilates efficiency gains through resource saving elsewhere ("rebound effect"); processes at different levels and with different temporal scales (e.g. faster changes at local ecosystem levels, slower changes at global ecosystem levels) are difficult to manage. Changing resource use in post-industrial and post-agricultural societies with new forms of rural development is hardly taken into account in resource management, although these are steps of system transformation in production (food or bioenergy), consumption (landscape, nature: production or recreation), and protection (nature/species: biodiversity maintenance).

The search for a new general theory seems misguided as with older general systems theory that evoked expectations to integrate social and natural scientific knowledge but remained an abstract conceptual framework and did not allow for in-depth analyses of different system types. With analyses of common pool resources, socialecological systems, global environmental change, forms of transdisciplinary ecological research unfold that support another theoretical reflection of nature-society interaction at different temporal and spatial scales. Such a theory differs from prior models and understandings of theory, it will be less generalized and predictive, more historically and culturally specific, open and plural, with combinations of several - thematically, temporally, spatially - specific theories; at its core lies the critical socioecological theory of interacting nature and society.

\section{Other variants of interdisciplinarity in rural and environmental research}

There are further discourses, linked to other interdisciplinary debates and disciplines that could be included in the critical analysis of socio-ecological systems. Only two more are mentioned because they paved the way towards present interdisciplinary approaches: anthropological and philosophical discourses. Critical variants of the anthropological discourse about man and environment include modern forms of philosophical anthropology (e.g. Scheler, Gehlen, Plessner; see Fischer, 2008) and interdisciplinary critical anthropology (Moscovici, 1968; Morin, 1973). The critical post-structuralist and feminist discourses (Butler, 1997) about organism, body and identity influenced by Foucault's thinking are less than these connected to debates of environmental problems; their cognitive interest is directed at the critical analysis of modern forms of power, subjectivity and rationality. In all these critical discourses the analysis of interaction between man, nature and society is taken up with the never finally answerable question about human nature. The plasticity and historical variation of human cultures veils that which has been called "human nature". This theme resurfaced in anthropology and philosophy, which indicates a need for new synthesis of knowledge about the human condition.

More limited philosophical discourses about nature and man developed in environmental ethics (Rolston, 1988) within the larger environmental discourse. The normative thinking in ethical theories cannot be easily integrated in theories of systemic interaction between society and nature. Whether these should be guided by culturally specific or trans-cultural global ethics of nature is controversial. With regard to that question it can be an advantage that ethics as practical philosophical discourse is no longer exclusively a philosophical domain. Ethical theory and reflection use more and more social-scientific and natural-scientific knowledge as their practice links. How then to solve the problem of "naturalistic fallacies" inherent in attempts to substantiate ethical values and norms with empirical knowledge is again a controversial debate.

\section{Conclusions - problems of knowledge integration}

Research about the interaction between society and nature in different fields as discussed above leaves the impression of redundancy, competing, disconnected knowledge production. Rather than criticizing redundancy, however, it can be seen as a discursive mechanism to drive knowledge production, evoke critical discussion and reflection. The interdisciplinary discourses support theoretical codification and reflection on knowledge as well as knowledge application. The emerging theory of interaction betwen society and nature as part of science and practice can be described (1) according to its main components, the theorems of symbolic and material societal relations to nature and its constituting processes of societal metabolism; (2) with regard to the unsolved problems and unsettled disputes about normative implications of knowledge practices; (3) in terms of empirical knowledge production and integration linked to it; (4) for applying scientific knowledge practically and discussing its use for formulating strategies of sustainable resource management. (5) Finally, one must ask what the emerging theory implies for further development of rural sociology.

(1) A theory of societal relations to nature helps to improve the analysis of the present environmental crisis and to refocus the diagnoses of problems and attempts to solve them. Symbolic and material relations as included in the process of societal metabolism and its changing socio-ecological regimes are the 
core themes of that theory which can be connected with other, more specific theories. The contradicting components and conflicts in that interaction, ecological distribution conflicts and their mitigation or unequal exchange, should be included in the theoretical description of interacting SES. The term societal metabolism, no longer a metaphor for problems waiting for interdisciplinary concepts and knowledge, allows us to describe and analyse critically global material and energy flows and the transformation of physical resources in the interaction between nature and society, in economic production, exchange and consumption.

(2) The unsettled problems and consequences of ecological distribution conflicts, unequal exchange and global resource flows are linked with normative implications of resource management and resource sharing, environmental justice, national and global redistribution of resources. Such normative problems require ethical discussion but cannot be limited to ethical problems of environmental justice, fair trade and political participation or participatory respource management - preliminary ideas that remain limited in their practical effects. For the redistribution of resources within and between generations and the "fair earth share" at which e.g. ecological footprint analyses are aiming, a more detailed and exact calculation of matter and energy use is required. This is available, but the consequences in terms of changes of power structures, lifestyles and resource consumption or resource sharing are still hardly discussed.

(3) Empirical knowledge and data from different fields of environmental research can be integrated with qualitative and quantitative synthesis methods (Weed, 2005). More complicated is the connection of empirical and theoretical knowledge, requiring other codification and interpretation processes than that for data, but methodologies are hardly available. Preliminary and bridging concepts such as SES and socio-ecological regimes may be helpful to build knowledge bridges from empirical research into future theories. Approaching sustainability or resilience in resource management is difficult; both abstract guiding concepts allow for manifold, incoherent or competing diagnoses of problems and interpretations of knowledge and data. In contrast, concepts of social-ecological systems and regimes can easily be specified for different historical, agrarian and industrial systems, and in combination with empirical data they allow for more exact and critical diagnoses of resource use problems.

(4) Scientific knowledge is applied in the practice of resource management through knowledge transfer, knowledge sharing or applied research. The theoretically influenced concepts in the research discussed above cannot be easily translated in terms of sustainable resource management to develop improved strategies that are urgently required as the critical discussion about panaceas based on research about common pool resources shows. The use of theoretical concepts is, however, necessary in resource management, requiring closer cooperation between scientists, politicians and resource managers, as demanded in transdisciplinarity: a "reflexive practice" of knowledge use which seems difficult to accept for many scientists.

(5) Rural sociology can gain from collecting the "disjecta membra" of a socio-ecological theory of societal relations to nature and of interdisciplinary environmental research. Adopting interdisciplinary knowledge can happen in several forms, not all of these compromise the (sub-) disciplinary nature and origins of rural sociology. However, it may be required to leave the universitarian "mode 1 "-discourses to make scientific knowledge fit for policy and practice. Not only environmental research shows that, also Buroway's discussion of a third wave of sociology (see Tovey, in this issue ${ }^{7}$ ). Three ways of interdisciplinary knowledge exchange in rural sociology have become visible. The first can be called "interdisciplinarity based on specialization" which allows the subdisciplinary status of rural sociology to be maintained, filtering new knowledge or discourses through the lenses of sociological specialisation in conventional or critical variants. In this university based form interdisciplinarity is mainly that of thematically specific research projects. The second variant of interdisciplinarity was discussed here, critical as against disciplinary specialization and oriented to the analysis of complex problems that do not fit in the disciplinary division of labour; interdisciplinary knowledge exchange requires use of knowledge from other disciplines and the crossing of boundaries between academic research and resource management through transdisciplinary approaches. Those are the dominant forms of interdisciplinary knowledge production today - outside universities, although often in cooperation with them. A third form of interdisciplinarity is emerging within the first two, not clearly identifiable as a new form. Here, interdisciplinarity is not only seen as scientific knowledge production and use, but as maintaining and developing a critical tradition of science, methodologically criticial about knowledge production and verification, and socially critical with regard to knowledge use, its consequences, questions of fairness and justice in resource use etc. Older traditions of critical and Marxist

7 Tovey, H., "Reflections from within: nature-society relations, interdisciplinarity, and knowledge production in rural sociology". 
theory belong to it, newer forms of critical sociology as by Bourdieu and Wacqant, Buroway's sociology, the critical anthropology of Moscovici, and the forms of critical social ecology and theory of nature society interaction. More answers can be expected from this third variant to the big questions about social and environmental problems that touch rural sociology.

\section{References}

Acheson, J.M., 2006. Institutional failures in resource management, Annual Review of Anthropology, 35, 117-134.

Agrawal, A., 2003. Sustainable governance of common pool resources: Context, methods, and politics, Annual Review of Anthropology, 32, 243-262.

Bahro, R., 1978. The Alternative in East Europe, London, New Left Books.

Becker, C.D., Ostrom, E., 1995. Human ecology and resource sustainability: The importance of institutional diversity, Annual Review of Ecology and Systematics, 26, 113-133.

Becker, E., Jahn, T., Wehling, P., 1992. Die civil society und die Krise der gesellschaftlichen Naturverhältnisse, in Evangelische Akademie Loccum (Ed.), Loccumer Protokolle, 75, 165-182.

Becker, E., Jahn, T., 2005. Societal relations to nature: Outline of a critical theory in the ecological crisis (http://www.isoe.de/ ftp/darmstadttext_engl.pdf).

Becker, E., Jahn, T. (Eds), 2006. Soziale Ökologie: Grundzüge einer Wissenschaft von den gesellschaftlichen Naturverhältnissen, Frankfurt am Main and New York, Campus.

Becker, S., Brand, U., 1996. Öko-Kapitalismus? Zur Regulation von Naturakkumulation und gesellschaftlichen Naturverhältnissen, in Bruch, M., Krebs, H.-P. (Eds), Unternehmen Globus: Facetten nachfordistischer Regulation, Münster, Westfälisches Dampfboot.

Bengtsson, J., Angelstam, P., Elmqvist, T., Emanuelsson, U., Folke, C., Ihse, M., Moberg, F., Nyström, M., 2003. Reserves, resilience and dynamic landscapes, Ambio, 32, 6, 389-395.

Bookchin, M., 2005. The Ecology of Freedom: The Emergence and Dissolution of Hierarchy, Edinburgh, AK Press.

Boulding, K., 1993. The Economics of the Coming Spaceship Earth, in Daly, H., Townsend, K. (Eds), Valuing the Earth: Economics, Ecology, Ethics, Cambridge (Mass.), The MIT Press.

Butler, J., 1997. The Psychic Life of Power: Theories in Subjection, Stanford, Stanford University Press.

Buttel, F., 2002. Environmental sociology and the sociology of natural resources: Institutional histories and intellectual legacies, Society and Natural Resources, 15, 205-211.

Catton, W., Dunlap, R., 1980. A new ecological paradigm for post-exuberant sociology, American Behavioral Scientist, 24, $15-47$.

Daly, H.E., 1992. Steady-State Economics, London, Earthscan Publications.

Debeir, J.-C., Deléage, J.-P., Hémery, D., 1986. Les Servitudes de la puissance : une histoire de l'énergie, Paris, Flammarion.

Dogan, M., 1996. The hybridization of social science knowledge, Library Trends, 45, 2, 296-314.
Enzensberger, H.M., 1973. Zur Kritik der politischen Ökologie, Kursbuch, 33, 1-42.

Escobar, A., 1999. After nature: Steps to an antiessentialist political ecology, Current Anthropology, 40, 1, 1-30.

Fischer, J., 2008. Philosophische Anthropologie: eine Denkrichtung des 20. Jahrhunderts, Freiburg, Alber.

Fischer-Kowalski, M., 2007. Socioecological transitions in human history and present, and their impact upon biodiversity. Presentation to the Second ALTER-Net Summerschool, Peyresq, Alpes-de-Haute-Provence, September.

Fischer-Kowalski, M., Haberl, H. (Eds), 2007. Socioecological Transitions and Global Change, Cheltenham and Northampton, Edward Elgar.

Folke, C., 2006. Resilience: the emergence of a perspective for social-ecological analyses, Global Environmental Change, 16, 253-267.

Forsyth, T., 2003. Critical Political Ecology, London and New York, Routledge.

Foster, J.B., 1999. Marx's theory of metabolic rift: Classical foundations for environmental sociology, American Journal of Sociology, 105, 366-402.

Geary, L.M., 1997. What people died of during the famine, in O'Grada, C. (Ed.), Famine 150: Commemorative Lecture Series, Dublin, Teagasc, University College.

Georgescu-Roegen, N., 1971. The Entropy Law and the Economic Process, Cambridge (Mass.), Harvard University Press.

Glaeser, B., Bruckmeier, K., Glaser, M., Krause, G., 2007. Socialecological systems analysis in coastal and marine areas: A path toward integration of interdisciplinary knowledge, in Lopes, P., Begossi, A. (Eds), Current Trends in Human Ecology, Newcastle upon Tyne, Cambridge Scholarly Publishing.

Hardin, G., 1968. The tragedy of the commons, Science, 162, $3859,1243-1248$.

Hornborg, A., McNeill, J.R., Martinez-Alier, J. (Eds), 2007. Rethinking Environmental History: World-System History and Global Environmental Change, Lanham, AltaMira Press.

Jacobs, J.A., Frickel, S., 2009. Interdisciplinarity: A critical assessment, Annual Review of Sociology, 35, 43-65.

Jamison, A., 2001. The Making of Green Knowledge, Cambridge and New York, Cambridge University Press.

Kapp, W., 1950. The Social Costs of Private Enterprise, Cambridge (Mass.), Harvard University Press.

Klein, J.T., 1990. Interdisciplinarity: History, Theory, and Practice, Detroit, Wayne State University.

Lipietz, A., 2003. A ecologia política e o future do marxismo, Ambiente E sociedade, 5, 2, 9-22.

Ludwig, D., 2001. The era of management is over, Ecosystems, 4, 758-764.

Martinez-Alier, J., 1995. Political ecology, distributional conflicts, and economic incommensurability, New Left Review, 211, 70-88.

Martinez-Alier, J., 2004. Ecological distribution conflicts and indicators of sustainability, International Journal of Political Economy, 34, 1, 13-30.

Millennium Ecosystem Assessment, 2005. Several reports and syntheses (www.maweb.org).

Mol, A., 2008. Environmental Reform in the Information Age: The Contours of Informational Governance, Cambridge, Cambridge University Press. 
Morin, E., 1973. Le Paradigme perdu : la nature humaine, Paris, Le Seuil.

Moscovici, S., 1968. Essai sur l'histoire humaine de la nature, Paris, Flammarion.

Nowotny, H., Scott, P., Gibbons, M., 2001. Re-Thinking Science: Knowledge and the Public in an Age of Uncertainty, Cambridge (UK), Polity Press.

Ostrom, E., 2009. A general framework for analyzing sustainability of social-ecological systems, Science, 325, 5939, 419422.

Polanyi, K., 1944. The Great Transformation, Boston, Beacon Press.

Rice, J., 2007. Ecological unequal exchange: Consumption, equity, and unsustainable structural relationships within the global economy, International Journal of Comparative Sociology, 48, 1, 43-72.

Robbins, P., 2004. Political Ecology: A Critical Introduction, Malden (Mass.) and Oxford (UK), Blackwell.

Rolston, H.S, 1988. Environmental Ethics: Duties to and Values in the Natural World, Philadelphia, Temple University Press.

Sachs, I., 2000. Understanding Development: People, Markets and the State in Mixed Economies, New Delhi and New York, Oxford University Press.

Sahlins, M., 1972. Stone Age Economics, London, Tavistock Publications.

Received 20 December 2009. Accepted 7 October 2010.
Schnaiberg, A., Gould, K.A., 1994. Environment and Society: The Enduring Conflict, New York, St. Martin's Press.

Sorokin, P., 1975. Hunger as a Factor in Human Affairs, Gainesville, University of Florida Press.

Steffen, W., Crutzen, P., McNeill, J.R., 2007. The Anthropocene: Are humans now overwhelming the great forces of nature?, Ambio, 36, 8, 614-621.

Walker, G., 2005. Sociological theory and the natural environment, History of the Human Sciences, 18, 77-106.

Wallerstein, I., 1974. The Modern World-System, I. Capitalist Agriculture and the Origins of the European World-Economy in the Sixteenth Century, New York, Academic Press.

Weed, M., 2005. "Meta interpretation": A method for the interpretive synthesis of qualitative research, Forum Qualitative Social Research, 6, 1 (http://www.qualitative-research.net/ index.php/fqs/article/view/508).

Wolf, E., 1982. Europe and the People Without History, Berkeley, Los Angeles and London, University of Californaia Press.

Young, O.R., Berkhout, F., Gallopin, G.G., Janssen, M.A., Ostrom, E., van der Leeuw, S., 2006. The globalization of socio-ecological systems: An agenda for scientific research, Global Environmental Change, 16, 304-316. 